\title{
Posts in Primary Teeth-Past to Present: A Review of Literature
}

\author{
Adeline G Martin ${ }^{1}$, Prathima Gajula Shivashakarappa ${ }^{2}$, Selvabalaji Arumugam ${ }^{3}$, Nandakumar Sundaramurthy ${ }^{4}$
}

\begin{abstract}
Early childhood caries is indeed a devastative situation for both patients' parents and pediatric dentists. The primary goal in treating severe early childhood caries is to restore normal function such as maintenance of mesiodistal and vertical dimension, prevention of alteration of mastication, phonetics (due to premature loss), development of parafunctional habits, and prevention of psychological problems affecting the self-esteem of a child. The restoration of primary dentition with extensive carious lesions is a complex clinical challenge of several dimensions. The severity of this condition in maxillary anterior teeth has prompted the extraction of teeth due to inadequate esthetic treatment options. The only concern with the severely destructed primary incisors is a lack of crown structure, which fails to support and adhere to a composite crown. Clinicians have preferred many restorative modalities for esthetic rehabilitation of badly decayed anterior primary teeth with numerous root canal retentive post and core systems with appropriate techniques to preserve those teeth until they are replaced by permanent teeth. This review highlights the various posts, their indications, principles, ideal properties, and the current concepts on their use in pediatric dentistry.
\end{abstract}

Keywords: Dentin post, Glass fiber post, Metal post, Post, Primary teeth.

International Journal of Clinical Pediatric Dentistry (2021): 10.5005/jp-journals-10005-2034

\section{INTRODUCTION}

The most common chronic disease of childhood is dental caries. Early childhood caries is carious lesions in very young children that clinically show a characteristic pattern. Maxillary central incisors and maxillary lateral incisors are the teeth most commonly involved followed by maxillary and mandibular first primary molars in both maxilla and mandible. ${ }^{1}$ It is a chronic, irreversible, multifactorial disease whose etiology is frequently associated with night-time feeding (breast or bottle-fed), poor oral hygiene habits, and the consumption of a more cariogenic diet. ${ }^{2}$ According to the AAPD guidelines, due to the unique and rampant nature of ECC, immediate therapeutic intervention is necessary to prevent further destruction and subsequent health problems. $^{3}$

Another significant factor that a pediatric dentist is concerned about is trauma. Parents typically visit the dentist when their children's teeth are severely broken and, too often, with root stumps left behind due to inadequate knowledge and lack of awareness on their part, making rehabilitation difficult. ${ }^{4}$

When sufficient tooth structure remains to be rehabilitated, it can be treated with conservative preparation and the application of a dentin bonding agent followed by preventive resin restoration. When there is sufficient tooth structure the carious coronal tooth structure can be restored with polycarbonate crowns, art glass crowns, anterior strip crowns, and veneered stainless steel crowns. ${ }^{5}$ Due to the lack of knowledge and awareness among parents, the majority of them consider treatment for their children only when their teeth are grossly broken and mere root stumps remain.

Primary anterior strip crowns were restrained to primary teeth with sufficient enamel, with the newly developed composite and dentinal bonding technique, although they cannot be used in grossly damaged primary anterior teeth with little or no enamel remaining after caries removal. ${ }^{6}$ But it remains a clinical challenge while restoring primary incisors with extensive carious lesions. For a long period, extraction was the most commonly used treatment for primary teeth with significant coronal destruction. ${ }^{7}$ These
1,2,4 Department of Pediatric and Preventive Dentistry, Indira Gandhi Institute of Dental Sciences, Puducherry, India

${ }^{3}$ Department of Paediatric and Preventive Dentistry, Adhiparashakthi Dental College and Hospital, Melmaruvathur, Tamil Nadu, India

Corresponding Author: Adeline G Martin, Department of Pediatric and Preventive Dentistry, Indira Gandhi Institute of Dental Sciences, Puducherry, India, Phone: +91 9626656636, e-mail: adem3195@gmail. com

How to cite this article: Martin AG, Shivashakarappa PG, Arumugam S, et al. Posts in Primary Teeth-Past to Present: A Review of Literature. Int J Clin Pediatr Dent 2021;14(5):705-710.

Source of support: Nil

Conflict of interest: None

teeth were quite often replaced by fixed or removable appliances, which pose issues with gingival health and patient cooperation. The restoration of grossly destruction maxillary incisors affected by early childhood caries has continued to be a major challenge for a pediatric dentist due to the insufficient amount of tooth structure available for bonding and behavioral problems in young children. ${ }^{8}$ In those larger lesions where little dental structure is left, conventional restorative procedures have been unsatisfactory and result in the use of prosthodontics appliances. In severely mutilated incisors where there is the involvement of pulpal tissue, pulpectomy has to be carried out and intracanal retention is necessary which allows building a post and core and then cementing an artificial crown. These posts were designed as composite resin posts, with the use of orthodontic pins, and as biological or natural posts. ${ }^{9}$

In clinical practice, evidence-based intracanal post-selection is very important, and pediatric dentists face significant problems due to the heterogeneity of data available on intracanal posts.

This literature review summarizes the various posts, their indications, ideal properties, and their use in pediatric dentistry.

(o) The Author(s). 2021 Open Access This article is distributed under the terms of the Creative Commons Attribution 4.0International License (https://creativecommons. org/licenses/by-nc/4.0/), which permits unrestricted use, distribution, and non-commercial reproduction in any medium, provided you give appropriate credit to the original author(s) and the source, provide a link to the Creative Commons license, and indicate if changes were made. The Creative Commons Public Domain Dedication waiver (http://creativecommons.org/publicdomain/zero/1.0/) applies to the data made available in this article, unless otherwise stated. 


\section{Materials and Methods}

A literature search of electronic databases (PubMed, Cochrane, and Google Scholar) and various journals (publication years-1999-2020) using medical subject headings were conducted. In the search, there were no filters activated and no language restrictions. Included references assessed the use of post and cores used in pediatric dentistry (4 reviews, 16 in vivo studies, 11 in vitro studies), and the articles were reviewed by two reviewers (both part of the authorship team).

\section{Importance of Primary Anterior Teeth}

- Primary maxillary anterior teeth dominate the physical appearance of a young child.

- Their loss of structure affects esthetics and also leads to compromised mastication.

- Poor phonetic pronunciation of tongue-tip consonants such as $e, t, d, s, s h$, and $c h$, as well as the labial sounds $f$ and $v$.

- Difficulties in the child's social and psychological adjustment, and the development of abnormal habits. ${ }^{10}$

\section{Consequences of Early Loss of Decayed Primary Incisors}

- Decreased masticatory efficiency, loss of vertical dimension development of abnormal oral habits like tongue-thrusting (parafunctional habits), and esthetic concerns. ${ }^{10}$

\section{Difficulties in Restoring Primary Anterior Teeth}

- Small, short crowns, and a large pulp chamber relative to crown size. ${ }^{11}$

- Thinner hard tooth substance and differences in the amount and distribution of minerals compared with permanent teeth lead to difficulties in achieving predictable and effective bonding of tooth-colored restorative materials. ${ }^{12}$

\section{Post and Core}

A one-piece foundation restoration for an endodontically treated tooth that comprises a post within the root canal and a core replacing missing coronal structure to form the tooth preparation (Glossary of prosthodontic terms 8$)^{13}$

\section{Ideal Properties of the Post}

- Should be resorbable and biocompatible.

- It should provide sufficient core retention and resistance without developing unwanted stresses within the remaining tooth structure.
- The post should be well adapted to the inner surface of the dentin for the coronal restoration to be retained. The appropriate fit of the post determines the preservation of the core restoration factor.

- Posts should have a good fatigue resistance to occlusal and shear loading, a high tensile strength, and a good distribution of forces that affects the root of the primary teeth. ${ }^{14,15}$

\section{Indications for Post in Primary Teeth}

- When more than one-half of the crown structure is lost, posts are indicated.

- Supragingival at least $1 \mathrm{~mm}$ of the tooth structure should be left. $^{15}$

\section{Advantages of Using Post in Primary Teeth}

- Posts primarily provide the necessary retention for the core.

- Posts provide support for the final restoration posts are indicated.

- Posts are used to reestablish the function and the esthetic appeal of severely mutilated primary anterior teeth.

- Posts improve the adhesion of strip crowns by increasing the surface area of the tooth structure on severely diseased primary incisors.

- Posts improve resistance to the mechanical load of the restored teeth. $^{15}$

\section{Post Space Preparation}

The root canal filling material in the root canal of the primary teeth is removed about $4 \mathrm{~mm}$ from the coronal part of the root canal. $1 \mathrm{~mm}$ of the restorative cement is placed over the root canal filling material. GIC button over the filling material can be given with the glass ionomer cement (Kumar). ${ }^{16}$ Other cements such as zinc polycarboxylate cement can also be used over the filling material. ${ }^{3}$

\section{Length of Post in Root Canal of Primary Teeth}

Short retentive posts are appropriate for primary teeth due to the physiological resorption that occurs, unlike the posts used in permanent dentition. The intracanal post should be placed at a depth of $3 \mathrm{~mm}$ (up to the cervical one-third of the canal) so that it does not interfere with the resorption of primary teeth or the eruption of permanent dentition. ${ }^{15}$ The level of the post-placement is checked and evaluated radiographically. The post should always be at or apical to the inter crestal bone level. Root fracture may occur if the post is inserted deeply into the radicular pulp space. ${ }^{17}$

\section{Classification of Post Used in Primary Teeth ${ }^{18}$}

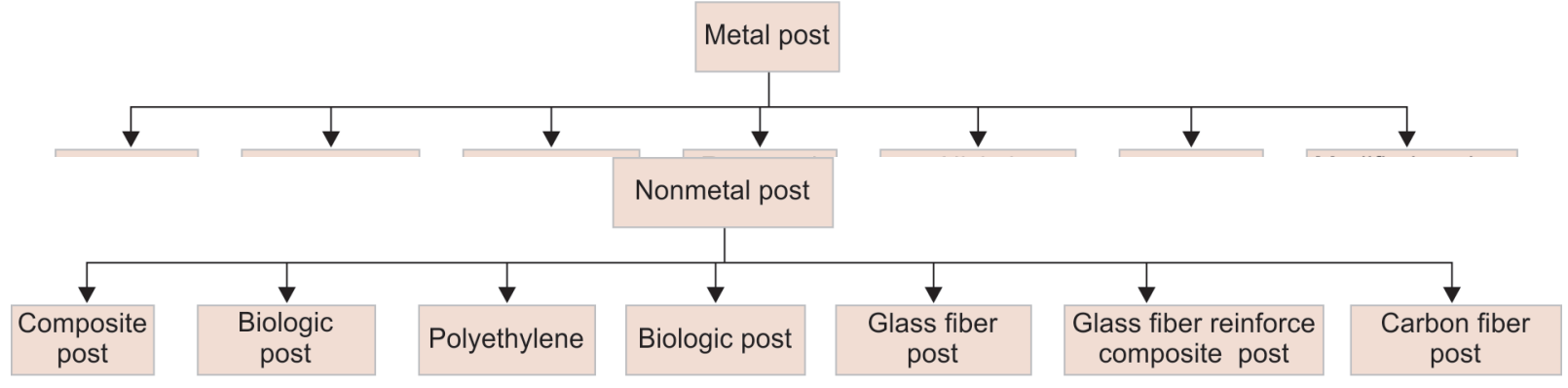




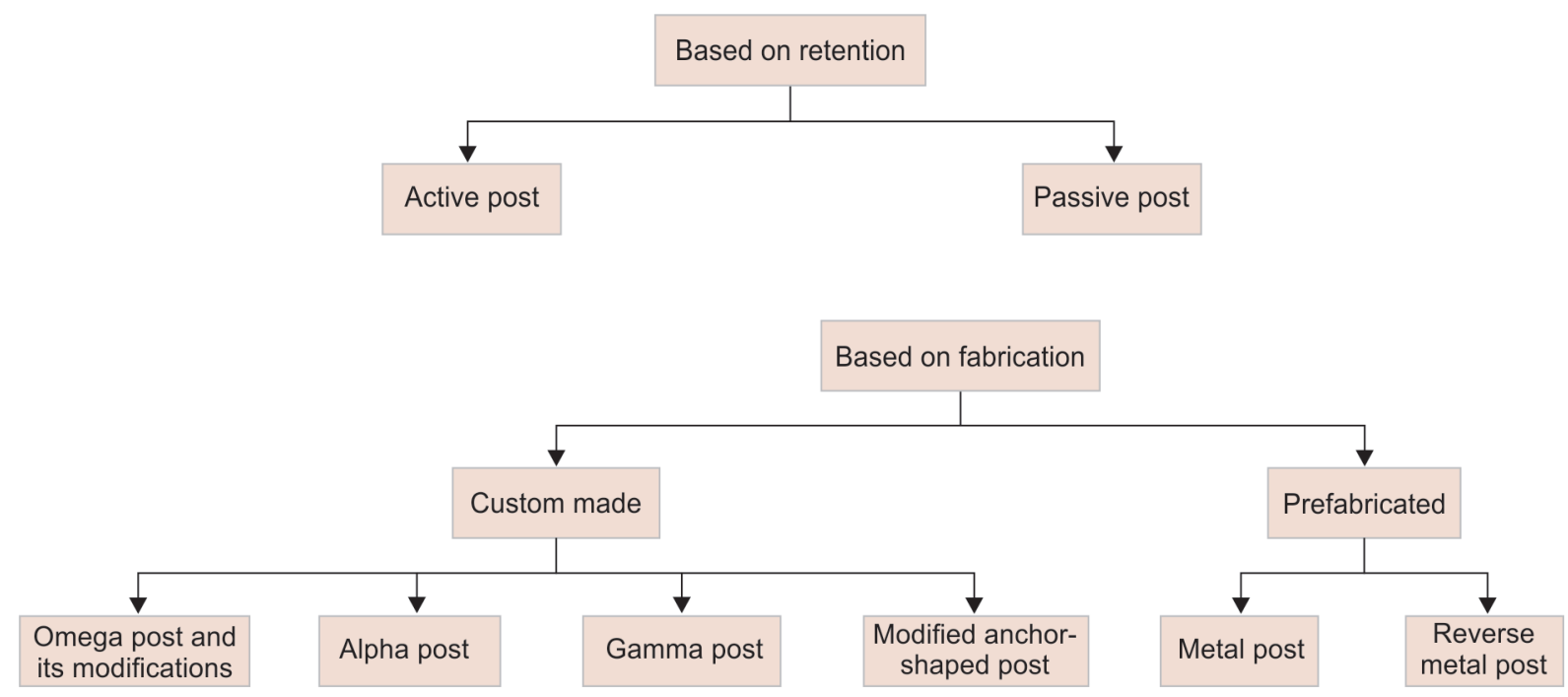

Various Posts Which are Used in Primary Teeth (Figs 1 to 6)

\begin{tabular}{|c|c|c|c|}
\hline Authors & Year & Post used & Inference \\
\hline $\begin{array}{l}\text { Rallan, Rallan, Navit } \\
\text { et al. }\end{array}$ & 2013 & Modified metal screw posts & $\begin{array}{l}\text { - Technique was simple, cost-efficient, and practical } \\
\text { - Disadvantage is the possibility of cracked root formation } \\
\text { following long-term function, especially in children with severe } \\
\text { occlusion or parafunctional habits. }{ }^{19}\end{array}$ \\
\hline Mortada and King & 2009 & Omega-shaped post & $\begin{array}{l}\text { - Prognosis was good with a survival rate of } 79.9 \% .^{20} \\
\text { - Successful esthetic rehabilitation }{ }^{21-23}\end{array}$ \\
\hline Gupta et al. & 2017 & & \\
\hline Ganesh & 2012 & & \\
\hline Ali & 2018 & & \\
\hline Aminabadi et al. & 2009 & Modified omega loop & $\begin{array}{l}\text { - With a follow-up of } 2 \text { years-proved to be efficient with } \\
\text { minimum chair side time and easy manipulation. }{ }^{24}\end{array}$ \\
\hline Arora et al. & 2019 & & $\begin{array}{l}\text { - Efficient results obtained from both clinical and radiographical } \\
\text { evaluation }{ }^{25}\end{array}$ \\
\hline Wanderley et al. & 1970 & Alpha-shaped & $\begin{array}{l}\text { - Achieved clinical success with sufficient reinforcement and } \\
\text { retention for coronal restoration. }{ }^{19}\end{array}$ \\
\hline Marcia et al. & 1999 & $\begin{array}{l}\text { Nickel chromium posts with } \\
\text { macro-retentive elements }\end{array}$ & $\begin{array}{l}\text { - Offers a wider distribution of occlusal force by both chemical } \\
\text { and mechanical adhesion. }{ }^{26}\end{array}$ \\
\hline Eshghi et al. & 2013 & Reversed metal post & - Have achieved clinical success in clinical scenarios. ${ }^{5}$ \\
\hline Vafaei et al. & 2016 & & $\begin{array}{l}\text { - Retention offered was due to the quadrangle shape of the head } \\
\text { inserted in the canal. }{ }^{27}\end{array}$ \\
\hline Garcia and Carranza & 1999 & Glass ionomer cement post & - Increased the retention of core restoration. ${ }^{28}$ \\
\hline Silvia et al. & 2002 & Composite resin short posts & $\begin{array}{l}\text { - Simpler technique. } \\
\text { - Adhesive type of failure was the most frequent type of failure } \\
\text { observed while using composite resin posts. }\end{array}$ \\
\hline $\begin{array}{l}\text { Motisuki, Santos-Pinto } \\
\text { and Giro }\end{array}$ & 2005 & Glass fiber post & $\begin{array}{l}\text { - After a follow-up period of } 1 \text { year demonstrated good retention } \\
\text { and esthetic results. }{ }^{2}\end{array}$ \\
\hline Mittal & 2015 & $\begin{array}{l}\text { Indirect composite post } \\
\text { restorations }\end{array}$ & $\begin{array}{l}\text { - Improved mechanical strength and better handling properties } \\
\text { are the advantages and satisfactory results. }{ }^{29}\end{array}$ \\
\hline $\begin{array}{l}\text { Lopes and } \\
\text { collaborators }\end{array}$ & 2001 & Polyethylene ribbon fibers & - Provides good retention and stability to the crown. ${ }^{30}$ \\
\hline
\end{tabular}




\begin{tabular}{|c|c|c|c|}
\hline Authors & Year & Post used & Inference \\
\hline \multirow[t]{2}{*}{ Gema et al. } & 2005 & $\begin{array}{l}\text { Pre-impregnated resin fibers } \\
\text { (Splint-it) }\end{array}$ & $\begin{array}{l}\text { Better fracture resistance was provided by pre-impregnated } \\
\text { fibers. } .^{30}\end{array}$ \\
\hline & & $\begin{array}{l}\text { Non pre-impregnated resin } \\
\text { fibers (glasSpan) }\end{array}$ & \\
\hline \multirow[t]{2}{*}{ Sharaf et al. } & 2002 & Glass fiber posts & $\begin{array}{l}\text { - Glass fiber posts-support and retain composite celluloid strip } \\
\text { crowns and offers better fracture resistance. }{ }^{31}\end{array}$ \\
\hline & & Composite posts & \\
\hline \multirow[t]{2}{*}{ Gujjar et al. } & 2010 & $\begin{array}{l}\text { Composite post, Orthodontic } \\
\text { "y" wire post }\end{array}$ & $\begin{array}{l}\text { - Good tensile strength and higher dislodging strength were } \\
\text { observed in the glass fiber post. }\end{array}$ \\
\hline & & Glass fiber post & $\begin{array}{l}\text { Bond failure in composite posts and orthodontic " } y \text { " wire posts } \\
\text { were more of bulk cohesive failure and all the glass fiber post } \\
\text { specimens showed an adhesive bond failure. }{ }^{32}\end{array}$ \\
\hline Al-Harbi and Dan & 2003 & $\begin{array}{l}\text { Fiber post systems and } \\
\text { ceramic posts. }\end{array}$ & - fiber post systems-more retentive. ${ }^{33}$ \\
\hline $\begin{array}{l}\text { Abd-Wahab Samaha } \\
\text { et al. }\end{array}$ & & $\begin{array}{l}\text { Carbon fiber posts and } \\
\text { ceramic post }\end{array}$ & $\begin{array}{l}\text { - Both carbon fiber posts and ceramic post-overall clinical success } \\
\text { rate of } 100 \% \text { reported at } 1,3 \text {, and } 6 \text { months follow-up. }{ }^{4}\end{array}$ \\
\hline Sawant et al. & 2017 & Fiber post & $\begin{array}{l}\text { - Provides a monoblock effect - proves to be clinically successful } \\
\text { in both primary and permanent teeth. }{ }^{34}\end{array}$ \\
\hline Grewal, Seth et al. & 2008 & Biological post & $\begin{array}{l}\text { Biologic post was clinic friendly, was an esthetic alternative for } \\
\text { other restorative materials available, less technique sensitive } \\
\text { and cost effective. }{ }^{35}\end{array}$ \\
\hline
\end{tabular}

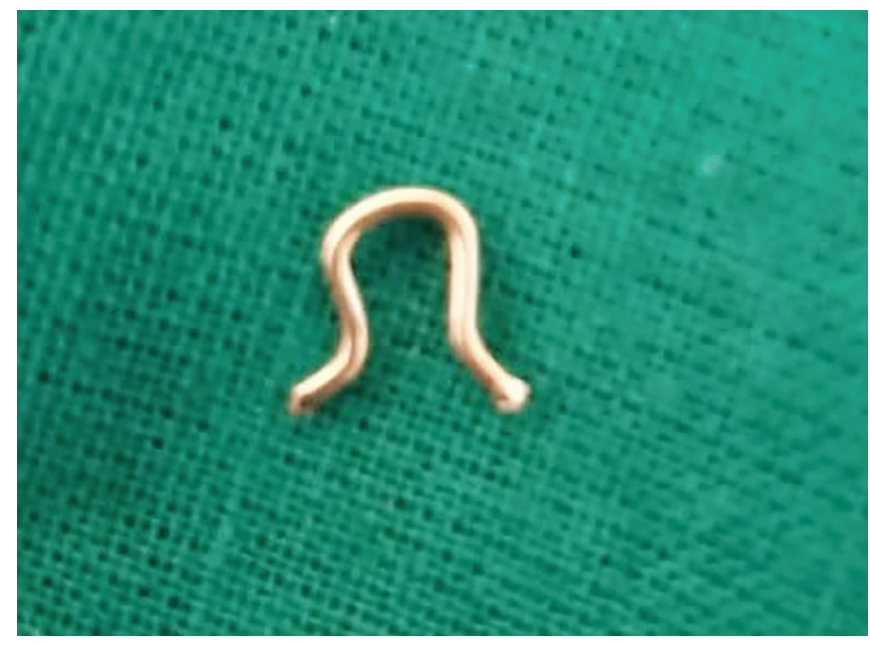

Fig. 1: Omega-shaped post

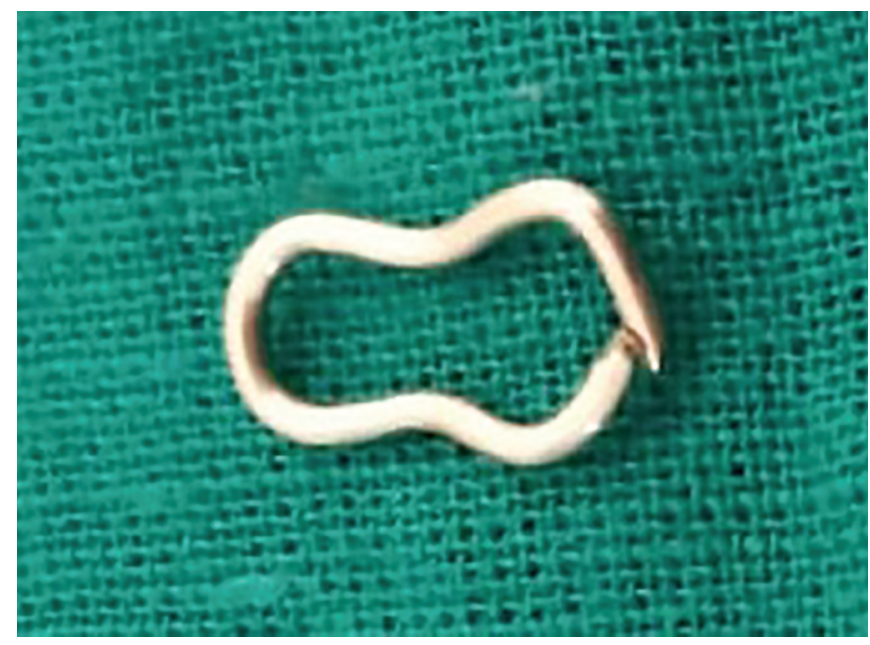

Fig. 3: Modified anchor-shaped post

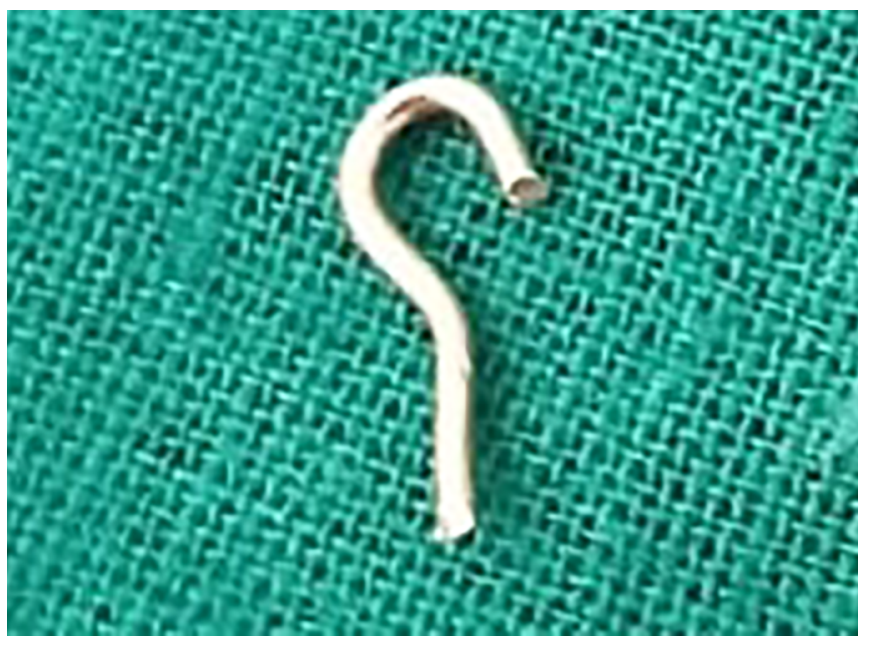

Fig. 2: Modified omega-shaped post

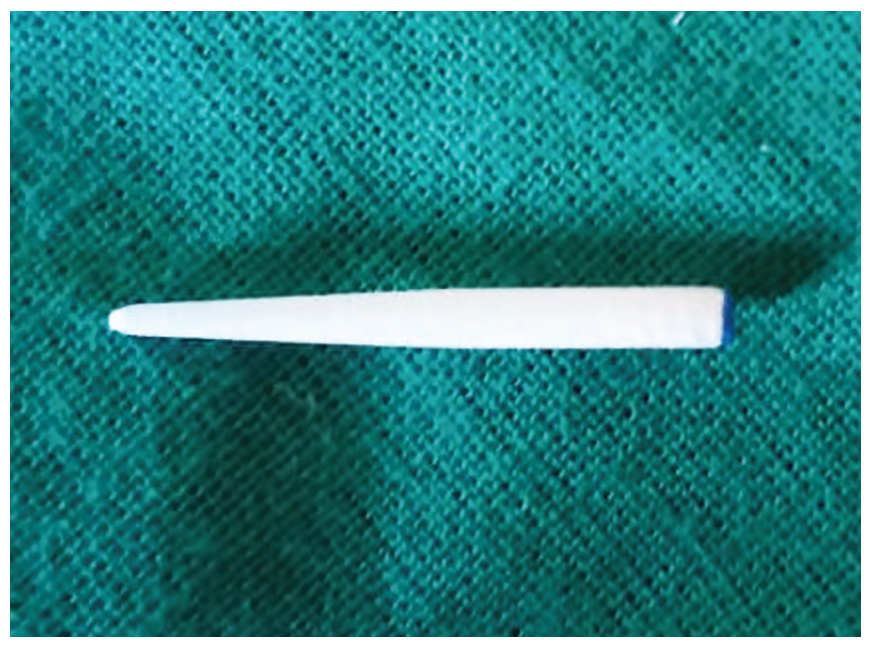

Fig. 4: Glass fiber post 


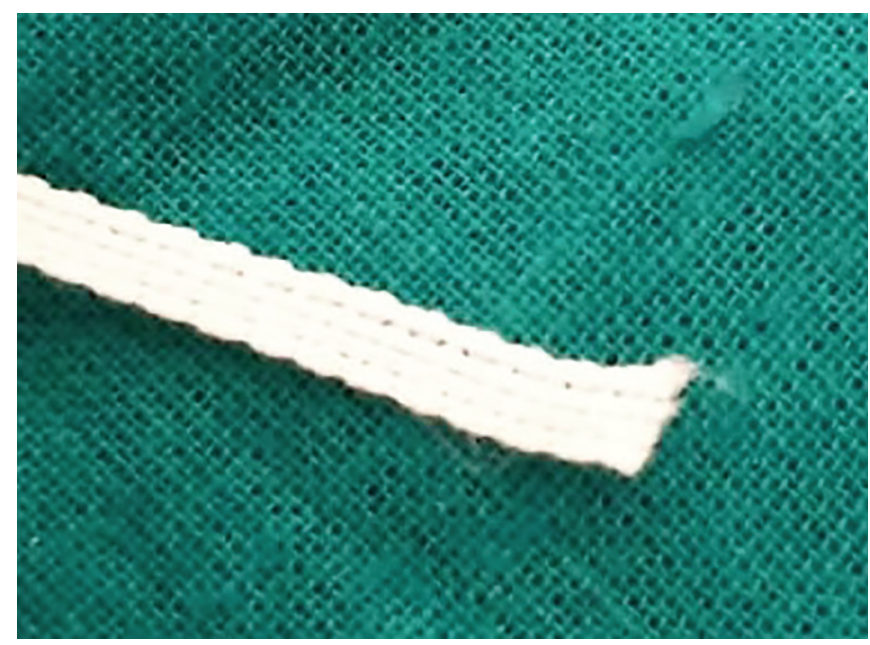

Fig. 5: Polyethylene post

\section{Core Restorations after Post-placement}

Single tooth crowns, like polycarbonate crowns, open-faced anterior stainless steel crowns, composite strip crowns, acrylic resin crowns, porcelain veneers, pedo jacket crowns, pedo pearls, art glass crowns, cheng crowns, dura crowns, new Millennium crowns could be used to restore the coronal portion of the teeth using either a direct or indirect technique. ${ }^{15}$

\section{Failure of a Post and Core Material}

Tooth loss, loss of restoration due to restoration and absolute debonding of the post, loss of restoration due to the canal and debonding of the post, and fracture of the post material. ${ }^{14}$

\section{Conclusion}

The evolution of posts, from cast metallic posts and preformed posts to esthetic fiber post designs, has been influenced by a variety of factors one of which is the need for esthetics. Along with this the functional harmony, biocompatibility, radiopacity, post design, fracture resistance, reinforcement, cementation, and retention were the factors that have led to the search for the ideal post. There is a variety of post materials and designs on the market each produced to meet a particular demand. It is therefore up to the practitioner's professional flexibility to select the post system that best fits the individual situation and techniques that obviate the patients' functional and esthetic demands and save chair time which is favorable during treatment of very young children.

\section{References}

1. Seraj B, Ghadimi S, Estaki Z, et al. Fracture resistance of three different posts in restoration of severely damaged primary anterior teeth: an in vitro study. Dent Res J 2015;12(4):372. DOI: 10.4103/1735-3327.161461.

2. Motisuki C, Santos-Pinto L, Giro EM. Restoration of severely decayed primary incisors using indirect composite resin restoration technique. Int J Paediat Dentis 2005;15(4):282-286. DOI: 10.1111/j.1365263X.2005.00645.x.

3. Srinivas NC, Jayanthi M. Post endodontic restoration of severely decayed primary dentition: a challenge to pediatric dental surgeon. World J Dentis 2011;2(1):67-69. DOI: 10.5005/jp-journals-10015-1057.

4. Abd EL, Sonia ES, Omar EM, et al., Clinical and laboratory evaluation of two different types of the post system in restoring destructed primary anterior teeth.

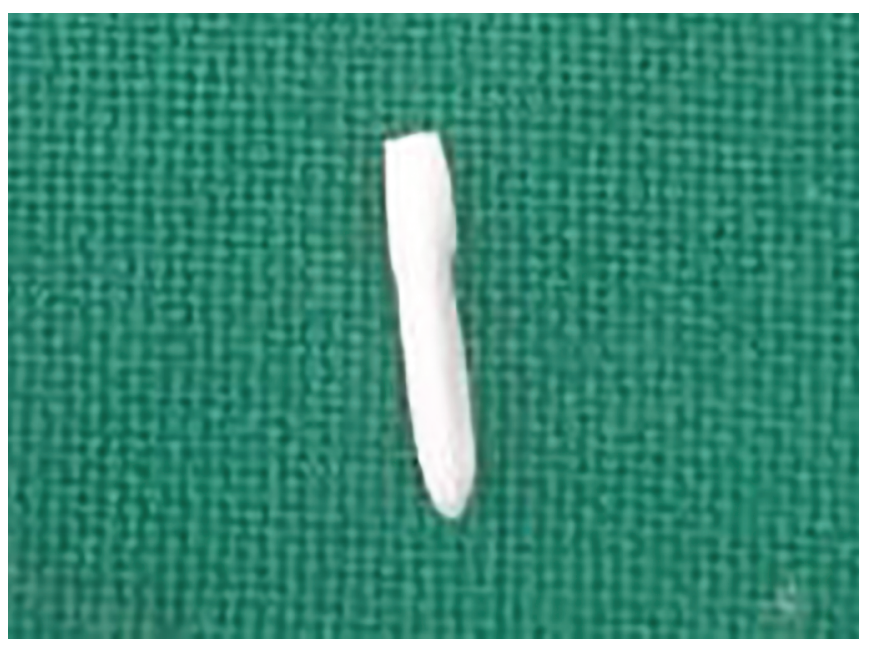

Fig. 6: Biological post

5. Eshghi A, Kowsari-Isfahan R, Khoroushi M. Evaluation of three restorative techniques for primary anterior teeth with extensive carious lesions: a 1-year clinical study. J Dentis Child 2013;80(2): 80-87.

6. Pithan S, de Sousa Vieira R, Chain MC. Tensile bond strength of intracanal posts in primary anterior teeth: an in vitro study. J Clin Pediat Dentis 2002;27(1):35-39. DOI: 10.17796/jcpd.27.1.7765 66w222426064.

7. Mittal N, Bhatia HP, Haider K. Methods of intracanal reinforcement in primary anterior teeth-assessing the outcomes through a systematic literature review. Int J Clin Pediat Dentis 2015;8(1):48. DOI: 10.5005/ jp-journals-10005-1282.

8. Walia R, Kakkar A, Ahuja L, et al. Rehabilitating grossly decayed primary anterior teeth: how and why. Int J Oral Health Dentis 2015;1(4):187-189. DOI: 10.5958/2395-499X.2015.00001.5.

9. Jathar P, Panse A, Desai AR. Acrylic crowns for esthetic rehabilitation of primary teeth. Int J Pedodon Rehabilitat 2018;3(1):42. DOI: 10.4103/ ijpr.ijpr_10_17.

10. Grosso FC. Primary anterior strip crowns: a new technique for severely decayed anterior primary teeth. J Pedodont 1987;11(4):375-384.

11. Waggoner W. Restoring primary anterior teeth. Pediatr Dent 2002;24(5):511-516.

12. Memarpour M, Shafiei F. Restoration of primary anterior teeth using intracanal polyethylene fibers and composite: an in vivo study. J Adhes Dentis 2013;15(1):85-91.

13. Fernandes AS, Shetty $S$, Coutinho I. Factors determining post selection: a literature review. J Prosthe Dentis 2003;90(6):556-562. DOI: 10.1016/j.prosdent.2003.09.006.

14. Al-Dhalaan R, Prosthodontic management of endodontically treated teeth; factors determining post selection, foundation restorations and review of success failure data.

15. Shah S, Bargale S, Anuradha KV, et al. Posts in primary teeth-a sile for better smile. J Adv Med Dent Sci Re 2016;4(1):58. DOI: 10.5455/ jrmds. 20164113.

16. Kumar R, Sinha A. Restoration of primary anterior teeth affected by early childhood caries using modified omega loops-a case report. Ann Dent 2014;2(4):24-26.

17. Mehra M, Grover R. Glassfiber post: an alternative for restoring grossly decayed primary incisors. Int J Clin Pediat Dentis 2012;5(2):159. DOI: 10.5005/jp-journals-10005-1158.

18. Suwarnkar SD, Prasad VN, Khan R, et al. Posts in primary teeth-a literature review. J Interdiscip Dent Sci 2017;6(2):3.

19. Rallan M, Rallan NS, Navit $P$, et al. Modified intracanal post for severely mutilated primary anterior teeth. Case Rep 2013;2013(Apr18 1):bcr2013009179. DOI: 10.1136/bcr-2013-009179. 
20. Mortada A, King NM. A simplified technique for the restoration of severely mutilated primary anterior teeth. J Clin Pediatr Dent 2004;28(3):187-192. DOI: 10.17796/jcpd.28.3.2554xv4 12644 ru13.

21. Gupta P, Bhatnagar P, Bais PS, et al. Management of mutilated primary anteriors: a challenge to pediatric dentist. Int J Oral Health Med Res 2017;4(1):45-47.

22. Ganesh R, Bose $S$, Moses J. Recreating esthetics in severely mutilated primary teeth-case reports. SRM J Res Dent Sci 2012;3(1):86.

23. Ali SM, Kiranmayi M, Raju SS. Esthetic rehabilitation of primary anterior teeth using double omega loop post: a report of two cases. Indian J Dent Adv 2018;9(4):231-234. Journal homepage: www.nacd. in.

24. Aminabadi NA, ZadehFarahani RM. The efficacy of a modified omega wire extension for the treatment of severely damaged primary anterior teeth. J Clin Pediat Dentis 2009;33(4):283-288. DOI: 10.17796/ jcpd.33.4.p8m168x8784719h3.

25. Arora R, Raiyani CM, Singh V, et al. Postendodontic restoration of severely decayed primary tooth using modified omega loop as a post. J Nat Sci Biol Med 2016;7(1):107. DOI: 10.4103/0976-9668. 175107.

26. Wanderley MT, Ferreira SLM, Rodrigues CM, et al. Primary anterior tooth restoration using posts.with macroretentive elements. Quintes Int 1999;30(6):431-436.

27. Vafaei A, Ranjkesh B, Lovschall $H$, et al. Survival of composite resin restorations of severely decayed primary anterior teeth retained by glass fiber posts or reversed-orientated metal posts. Int J Clin Pediat Dentis 2016;9(2):109. DOI: 10.5005/jp-journals-10005-1344.

28. Carranza F, Garcia GF. Esthetic restoration of primary incisors. Am J Dent 1999;12(2):55-58.

29. Mittal N, Kumar P. Restoring the young smile via indirect composite restorations. Int J Dent Oral Health 2015;2(2).

30. Island G, White GE. Polyethylene ribbon fibers: a new alternative for restoring badly destroyed primary incisors. J Clin Pediat Dentis 2005;29(2):151-156. DOI: 10.17796/jcpd.29.2.0221wmj44wg66220.

31. Sharaf AA. The application of fiber core posts in restoring badly destroyed primary incisors. J Clin Pediatr Dent 2002;26(3):217-224. DOI: $10.17796 / j c p d .26 .3 . y 3660 \times 50 n 5 I 0 j v 0 p$.

32. Gujjar KR, Indushekar KR. Comparison of the retentive strength of 3 different posts in restoring badly broken primary maxillary incisors. J Dentis Child 2010;77(1):17-24.

33. Al-Harbi F, Dan N. In vitro assessment of retention of four esthetic dowels to resin core foundation and teeth. J Prosthet Dent 2003;90(6):547-555. DOI: 10.1016/j.prosdent.2003.09.014.

34. Sawant $A$, Chunawalla $Y$, Morawala A, et al. Evaluation of novel glass fiber-reinforced composite technique for primary anterior teeth with deep carious lesions: a 12-month clinical study. Int J Clin Pediat Dentis 2017;10(2):126. DOI: 10.5005/jp-journals-10005-1421.

35. Grewal N, Reeshu S. Biological restorations: an alternative esthetic treatment for restoration of severely mutilated primary anterior teeth. Int J Clin Pediat Dentis 2008;1(1):42. DOI: 10.5005/ jp-journals-10005-1008. 